\title{
FACTORS THAT AFFECT USING ASPECT NUMBERS ON STUDENTS SDN IN THE PANGKAJENE DISTRICT PANGKEP REGENCY
}

\author{
Samsiah $^{1)}$ \\ ${ }^{1}$ SD Negeri 1 Pangkajene, Kab. Pangkep, Sulawesi Selatan, Indonesia
}

\begin{abstract}
The government has implemented various efforts in order to improve the quality of education, especially in the field of basic education. The quality of education concerns many interrelated issues, including the quality of learners, the quality of educators (teachers) and other education personnel and facilities and infrastructure. At the operational level, the issue of quality of education is very pleased with the quality of teaching teachers and student learning. Based on that, the researcher is encouraged to analyze the factors influencing the mastery of the aspect of the number in the elementary school teacher in Pangkajene sub-district, Pangkep regency. This research belongs to survey research that is descriptive-correlative and explorative with population of all teachers of SD Negeri in Pangkajene Sub-district of Pangkep Regency. Sampling was done with a sample of considerations. Data obtained by using the instrument in the form of questionnaire and test about aspect of number. The data were processed using descriptive and inferential statistical analysis. The result of descriptive analysis shows that the mastery of number aspect in elementary school teacher is in low category. The results of inferential analysis indicate that the level of education, age and sex rate together affect the mastery of number aspect in elementary school teachers in Pangkajene sub-district, Pangkep regency. The results of explorative research indicate that other factors affecting the mastery of the number aspect are education and training, educational background, shift of teaching level, the role of teacher of mathematics guide, motivation and incentive for the achieving teacher.
\end{abstract}

Keywords: Level of education; age, gender, \& number

PENDAHULUAN

Pendidikan matematika pada jenjang pendidikan dasar mempunyai peranan yang sangat penting sebab jenjang ini merupakan pondasi yang sangat menentukan dalam membentuk sikap, kecerdasan, dan kepribadian anak. Namun kenyataan menunjukkan banyaknya keluhan dari murid tentang pelajaran matematika yang sulit, tidak menarik, dan membosankan. Keluhan ini secara langsung maupun tidak langsung akan sangat berpengaruh terhadap prestasi belajar matematika pada setiap jenjang pendidikan. Meskipun upaya untuk mengatasi hasil belajar matematika yang rendah telah dilakukan oleh pemerintah. Seperti penyempurnaan kurikulum, pengadaan buku paket, peningkatan pengetahuan guru-guru melalui penataran dan pelatihan, peningkatan kualifikasi pendidikan guru serta melakukan berbagai penelitian terhadap faktor-faktor yang diduga mempengaruhi hasil belajar matematika. Namun kenyataan menunjukkan bahwa hasil belajar masih jauh dari yang diharapkan.

Pendidikan dasar adalah bagian terpadu dari sistem pendidikan nasional. Pendidikan dasar merupakan pendidikan yang lamanya 9 (sembilan) tahun yang diselenggarakan selama 6 (enam) tahun di SD dan 3 (tiga) tahun di SMP atau satuan pendidikan yang sederajat. 
Pendidikan dasar bertujuan untuk memberikan bekal kemampuan dasar pada siswa untuk mengembangkan kehidupan sebagai pribadi, anggota masyarakat, warga negara, dan anggota umat manusia serta mempersiapkan siswa untuk mengikuti pendidikan menengah.

Kurikulum pendidikan dasar yang berkenaan dengan sekolah dasar menekankan kemampuan dan keterampilan dasar, yaitu "Baca, Tulis, dan Hitung" (Calistung) sebagaimana tercermin dalam kemampuan dan keterampilan (Baca, Tulis, dan Bicara) serta berhitung (menambah, mengurang, membagi, mengali, mengukur sederhana, dan memahami bentuk geometri) yang dapat diterapkan dalam kehidupan sehari-hari.

Menurut Slameto (2003:54) penyebab rendahnya prestasi belajar matematika siswa sekarang ini tidak terlepas dari dua faktor umum. Pertama, faktor dari dalam diri siswa itu sendiri (faktor internal). Faktor ini banyak didominasi oleh kondisi kecerdasan termasuk kecerdasan intelektual dan kecerdasan emosional. Faktor kedua, yakni bersumber dari luar individu siswa (faktor eksternal). Faktor ini beraneka ragam, diantaranya: (1) faktor lingkungan, (2) kurikulum, (3) sarana dan prasarana, (4) kemampuan professional guru (5) dan sebagainya.

Salah satu kelemahan yang disandang oleh sebagian guru adalah kerendahan tingkat kompetensi profesionalisme mereka. Penguasaan mereka terhadap materi dan metode pengajaran masih berada di bawah standar (Syah, 2006:221).

Mata pelajaran matematika pada satuan pendidikan Sekolah Dasar/Madrasah Ibtidaiyyah meliputi 3 (tiga) aspek yakni: (1) bilangan, geometri dan pengukuran, (3) pengolahan data. Berdasarkan ketiga aspek ini, bilangan menempati urutan pertama, ini berarti bilangan merupakan aspek yang sangat fundamental dari semua aspek dalam matematika, karena tanpa bilangan kita tidak dapat berbuat apa-apa dalam matematika, apapun kegiatan yang kita lakukan baik dalam matematika maupun dalam kehidupan kita sehari-hari sangat erat kaitannya dengan bilangan.

Pentingnya menguasai bilangan ini diungkapkan oleh matematikawan Pythagoras dalam Ediati (materi 1 seminar online WRM-BUKAMATA), "If Number rules the universe, Number is merely our delegate to the throne, for we rule Number." Yang artinya Apabila bilangan mengatur alam semesta, Bilangan adalah kuasa yang diberikan kepada kita guna mendapatkan "mahkota", untuk itu kita menguasai bilangan. Ungkapan ini tentu saja sangat beralasan, karena hampir tidak ada segi-segi kehidupan di jagat raya ini yang tidak berhubungan dengan bilangan.

Berbagai alasan mengapa bilangan harus dikuasai sejak dini antara lain: (1) agar dapat menguasai matematika, (2) agar mampu memahami alam semesta, (3) agar bisa membangun gedung, (4) agar bisa bersikap adil, (5) agar dapat mengevaluasi target, (6) agar terbiasa berpikir logis, (7) agar tidak mudah tertipu, (8) dan masih banyak manfaat lainnya.

Kompetensi yang harus dimiliki oleh guru sekolah dasar pada aspek bilangan adalah mengembangkan penguasaan siswa terhadap keterampilan serta mengembangkan keterampilan siswa dalam melakukan pengerjaan hitung bilangan (Standar Kompetensi Guru SD). Artinya guru sekolah dasar sebagai 
guru kelas harus mampu menguasai aspek bilangan, baik dari segi keterampilannya maupun dari segi penggunaannya namun ada indikasi bahwa penguasaan aspek bilangan guru-guru SD Negeri di kecamatan Pangkajene belum memadai.

Berdasarkan kenyataan ini, penulis ingin mengungkap penguasaan aspek bilangan pada guru sekolah dasar negeri di Kecamatan Pangkajene Kabupaten Pangkep yang meliputi materi ajar kelas IV hingga materi ajar kelas VI sebagai salah satu solusi untuk memperbaiki atau meningkatkan prestasi belajar pada umumnya dan khususnya prestasi belajar matematika di Kabupaten Pangkep, dengan mempertimbangkan tingkat pendidikan, umur atau usia serta jenis kelamin.

Berdasarkan uraian yang telah dikemukakan pada latar belakang, maka dibawah ini dikemukakan rumusan masalah sebagai berikut: (1) Bagaimanakah gambaran penguasaan aspek bilangan pada guru SD Negeri di Kecamatan Pangkajene Kabupaten Pangkep? (2) Bagaimanakah gambaran penguasaan aspek bilangan pada guru SD Negeri di Kecamatan Pangkajene Kabupaten Pangkep ditinjau dari tingkat pendidikan? (3) Bagaimanakah gambaran penguasaan aspek bilangan pada guru SD Negeri di Kecamatan Pangkajene Kabupaten Pangkep ditinjau dari umur? (4) Bagaimanakah gambaran penguasaan aspek bilangan pada guru SD Negeri di Kecamatan Pangkajene Kabupaten Pangkep ditinjau dari jenis kelamin? (5) Apakah ada pengaruh tingkat pendidikan terhadap penguasaan aspek bilangan pada guru SD Negeri di Kecamatan Pangkajene Kabupaten Pangkep? (6) Apakah ada pengaruh umur terhadap penguasaan aspek bilangan pada guru SD Negeri di Kecamatan Pangkajene Kabupaten Pangkep? (7) Apakah ada perbedaan penguasaan aspek bilangan antara guru laki-laki dan guru perempuan pada SD Negeri di Kecamatan Pangkajene Kabupaten Pangkep? (8) Apakah ada pengaruh secara bersama-sama tingkat pendidikan, umur, dan jenis kelamin terhadap penguasaan aspek bilangan pada guru SD Negeri di Kecamatan Pangkajene Kabupaten Pangkep?

Pada dasarnya penelitian ini bertujuan memperoleh jawaban terhadap pertanyaan-pertanyaan yang telah dirumuskan pada masalah penelitian. Secara rinci tujuan penelitian dapat dirumuskan sebagai berikut: (1) Untuk mendeskripsikan penguasaan aspek bilangan pada guru SD Negeri di Kecamatan Pangkajene Kabupaten Pangkep (2) Untuk mendeskripsikan penguasaan aspek bilangan pada guru SD Negeri di Kecamatan Pangkajene Kabupaten Pangkep ditinjau dari tingkat pendidikan (3) Untuk mendeskripsikan penguasaan aspek bilangan pada guru SD Negeri di Kecamatan Pangkajene Kabupaten Pangkep ditinjau dari umur. (4) Untuk mendeskripsikan penguasaan aspek bilangan pada guru SD Negeri di Kecamatan Pangkajene Kabupaten Pangkep ditinjau dari jenis kelamin. (5) Untuk mengetahui pengaruh tingkat pendidikan terhadap penguasaan aspek bilangan pada guru SD Negeri di Kecamatan Pangkajene Kabupaten Pangkep. (6) Untuk mengetahui pengaruh umur terhadap penguasaan aspek bilangan pada guru SD Negeri di Kecamatan Pangkajene Kabupaten Pangkep. (7) Untuk mengetahui perbedaan penguasaan aspek bilangan antara guru laki-laki dan guru perempuan pada SD Negeri di Kecamatan Pangkajene Kabupaten Pangkep. (8) Untuk mengetahui ada atau tidaknya pengaruh secara 
bersama-sama tingkat pendidikan, umur, dan jenis kelamin terhadap penguasaan aspek bilangan pada guru SD Negeri di Kecamatan Pangkajene Kabupaten Pangkep.

Hasil penelitian ini diharapkan dapat memberikan manfaat antara lain sebagai berikut: (1) Sumbangan pemikiran kepada para pembuat keputusan pendidikan terutama pada jajaran Dinas Pendidikan Nasional Kabupaten Pangkep dalam hal usaha pembinaan dan peningkatan kompetensi guru dalam melaksanakan proses belajar-mengajar. (2) Menjadi masukan bagi kepala sekolah untuk berupaya meningkatkan kompetensi guru dalam rangka pengembangan dan peningkatan pengetahuan guru melalui KKG dan sejenisnya. (3) Menjadi masukan bagi guru dalam melaksanakan proses belajar- mengajar yang pada akhirnya akan meningkatkan kualitas proses pembelajaran di sekolah. (4) Menjadi bahan pembanding atau referensi bagi peneliti lain untuk meneruskan penelitian serupa dalam ruang lingkup yang lebih luas. (5) Memperkaya khasanah ilmu pengetahuan, khususnya dalam pendidikan matematika.

\section{Arti guru dahulu dan sekarang}

Pada zaman dahulu, jauh sebelum era globalisasi informasi, profesi dan posisi guru konon dihormati sebagaimana priyayi. Dalam berbagai upacara dan perayaan, mereka duduk dideretan utama bersama para demang alias wedana.

Secara ekonomis, penghasilan guru pada waktu itu memadai bahkan lebih. Secara psikologis, harga diri (self-esteem) dan wibawa mereka juga tinggi, sehingga para orangtua pun berterima kasih bila anak-anak "dihajar" guru kalau berbuat kurang ajar dan mengganggu. Singkat cerita, posisi guru di mata berbagai kalangan masyarakat pada masa lalu sangat tinggi dan terhormat.

Namun, kini keadaan guru telah berubah drastis. Profesi guru adalah profesi yang "kering", dalam arti kerja keras para guru membangun sumber daya manusia (SDM) hanya sekadar untuk mempertahankan kepulan asap dapur saja. Bahkan harkat dan derajat guru di mata masyarakat sangat merosot, seolah-olah menjadi warga negara kelas dua (second class). Kemerosotan ini terkesan karena guru berpenghasilan jauh dibawah rata-rata dari kalangan professional lainnya seperti dokter, pengacara, dll.

Sementara itu, wibawa para guru di mata murid- murid pun kian jatuh. Murid- murid masa kini, cenderung menghormati guru karena ingin memperoleh nilai tinggi tanpa kerja keras, atau ingin mendapat permintaan maaf dan maklum karena tugas yang diberikan telat, atau berbagai alasan lain. Singkat cerita, murid menghormati gurunya karena hanya ingin mendapatkan keuntungan.

Kelemahan yang disandang sebagian guru itu dikarenakan ada sebagian guru yang berpenampilan tidak mendidik serta rendahnya tingkat kompetensi profesionalisme. Penguasaan terhadap materi dan metode pengajaran masih berada di bawah standar (Syah, 2006:221).

\section{Arti guru masa mendatang}

Dalam Kamus Besar Bahasa Indonesia edisi kedua (1994:330) guru diartikan sebagai orang yang pekerjaannya (mata pencahariannya, profesinya) mengajar, sedangkan dalam bahasa Inggris adalah teacher yang memiliki arti yang sederhana, yakni A person whose occupation is teaching others (McLeod, 1989), artinya guru adalah seseorang yang pekerjaannya mengajar orang lain. 
Lain halnya dalam bahasa Sansekerta, secara harafiahnya guru berarti "berat". Guru diartikan sebagai seorang pengajar suatu ilmu. Dan arti umum dari guru adalah pendidik dan pengajar pada pendidikan anak usia dini jalur sekolah atau pendidikan formal, pendidikan dasar, dan pendidikian menengah. Selanjutnya, kegiatan mengajar yang dilakukan guru itu tidak hanya berorientasi pada kecakapan- kecakapan berdimensi ranah cipta saja, tetapi kecakapan- kecakapan yang berdimensi ranah rasa dan karsa.

Didalam mengajar, khususnya dalam bidang studi matematika seorang guru dituntut untuk menguasai bahan ajar yang akan diajarkan, baik dari segi konsep, logika, berhitung dan generalisasinya. Dalam perspektif psikologi pendidikan, mengajar pada prinsipnya berarti proses perbuatan seseorang (guru) yang membuat orang lain (siswa) belajar, dalam arti mengubah seluruh dimensi prilakunya.

Oleh sebab itu, peranan guru dalam organisasi sekolah sangat penting, karena sebagai faktor penentu dalam kesuksesan setiap usaha pendidikan, tanpa mengabaikan peran dari unsur-unsur lainnya. Hal ini disebabkan karena guru merupakan ujung tombak terselenggaranya proses belajar mengajar di sekolah.

Dari berbagai definisi, penulis mengartikan guru sebagai seorang yang karena kualifikasi pendidikannya sehingga diberikan tugas sebagai tenaga pendidik mulai jenjang Taman Kanak-kanak (TK), jenjang Sekolah Dasar (SD), jenjang Sekolah Menengah Pertama (SMP) serta jenjang Sekolah Menengah Atas (SMA) atau yang sederajat.

\section{Tingkat pendidikan}

Dalam reformasi pengembangan sumber daya manusia, maka pendidikan memegang peranan yang sangat menentukan. Manusia dengan profesinya dituntut memiliki keahlian khusus atau kompetensi dimana hal tersebut sangat dipengaruhi oleh tingkat pendidikan formal yang telah ditempuhnya. Adapun pendidikan formal yang dimaksud adalah tingkat pendidikan yang bersifat formal sesuai yang dikemukakan oleh Ahmadi (dalam Ma'rufi, 2006:28) bahwa: " Pendidikan formal adalah pendidikan yang berlangsung secara teratur, bertingkat dan mengikuti syarat-syarat tertentu secara ketat."

Pidarta (1997) mengemukakan bahwa pendidikan adalah upaya menuntun segala kekuatan yang ada pada peserta didik agar mereka sebagai manusia dan sebagai anggota masyarakat mendapat keselamatan dan kebahagiaan yang setinggi-tingginya. Selain itu, pendidikan diartikan pula sebagai proses seseorang mengembangkan kemampuan sikap dan tingkah laku lainnya di dalam masyarakat tempat mereka hidup dan proses sosial yang terjadi pada orang yang dihadapkan pada pengaruh perkembangan kemampuan sosial, kemampuan individu yang optimal.

pendidikan merupakan proses pengembangan sumber daya manusia yang dilakukan dengan tujuan yang mengarah kepada peningkatan pola pikir, tingkah laku, pengetahuan, kecerdasan, keterampilan sehingga mampu menyesuaikan diri dengan lingkungan dimana ia berada. Manusia yang memperoleh peningkatan pada aspek kognitif, afektif dan psikomotorik melalui pendidikan yang berlangsung secara teratur, bertingkat dan mengikuti syarat-syarat tertentu secara ketat yang disebut pendidikan formal. Jadi, pendidikan sebagai proses seseorang 
mengembangkan kemampuan sikap dan tingkah lakunya di dalam masyarakat tempat mereka hidup dan proses sosial yang terjadi pada orang yang dihadapkan pada pengaruh perkembangan kemampuan sosial, kemampuan individu secara optimal dan manusiawi.

\section{Umur}

Pada umumnya hal yang berkaitan dengan perkembangan umur berkisar kepada persoalan yang berhubungan dengan pengaruh pembawaan dan lingkungan bagi perkembangan seseorang. Sifat pembawaan itu mempunyai pengaruh yang sangat penting bagi perkembangan umur seseorang. Dari perkembangan itu lahir kedewasaan dengan sifat-sifat tertentu dengan klasifikasi umur tertentu pula (Mustaqim, 1990).

Menurut Kamus Besar Bahasa Indonesia (1994:1103) umur atau usia diartikan sebagai lama waktu hidup atau ada (sejak dilahirkan atau diadakan). Sementara menurut Wikepedia Indonesia Umur atau usia adalah satuan waktu yang mengukur waktu keberadaan suatu benda atau makhluk, baik yang hidup maupun yang mati. Semisal, umur manusia dikatakan lima belas tahun diukur sejak dia lahir hingga waktu umur itu dihitung.

Umur dapat diklasifikasikan motifnya antara lain: umur emosi, yakni taraf kesanggupan seseorang untuk mengalami perasaan-perasaan tertentu; umur fisik yakni taraf kematangan bagian-bagian tubuh seseorang; umur kependidikan, yaitu tingkat kemajuan seseorang dibandingkan dengan kemajuan seseorang yang sudah duduk ditingkat tertentu; umur kronologis, yakni umur menurut kalender; umur mental, yakni umur menurut rata-rata perkembangan mental anak seusia umur moral, yakni taraf kesanggupan anak dalam bergaul dengan orang lain.

Jenis perhitungan usia terbagi atas: (1) usia kronologis, (2) usia mental, (3) usia biologis. Usia kronologis adalah perhitungan usia yang dimulai dari saat kelahiran seseorang sampai dengan waktu penghitungan usia. Usia mental adalah perhitungan usia yang didapatkan dari taraf kemampuan mental seseorang. Misalkan seorang anak secara kronologis berusia empat tahun akan tetapi masih merangkak dan belum dapat berbicara dengan kalimat lengkap dan menunjukkan kemampuan yang setara dengan anak berusia satu tahun, maka dinyatakan bahwa usia mental anak tersebut adalah satu tahun. Usia biologis adalah perhitungan usia berdasarkan kematangan biologis yang dimiliki oleh seseorang.

Suatu umur didefinisikan sebagai rata-rata jumlah tahun kehidupan yang masih dijalani seseorang dalam situasi tertentu yang berlaku dilingkungan masyarakatnya pada usia tertentu merupakan indikator yang baik untuk menunjukkan tingkat sosio-ekonomi secara umum, tugas masing-masing. Indikator yang sering dipakai adalah angka harapan hidup yakni angka tersebut berkisar pada tahun kurang lebih 40 tahun pada Negara berkembang dan 70 tahun pada Negara maju. Angka harapan hidup di indonesia berdasarkan analisis sensus penduduk tahun 2000 sebesar 65 tahun.

Faktor umur dapat pula diasumsikan berpengaruh negatif, sebagaimana hasil studi yang dilakukan oleh Nawawi (dalam Tiro, 2000) tentang hak pengelolaan tanah Negara yang menunjukkan bahwa koefisien regresi untuk umur adalah negatif yaitu $-1,290$. Ini berarti bahwa makin tua umur aparat makin rendah tingkat pelaksanaan hak pengelolaan tanah Negara, tetapi faktor umur secara 
individual signifikan. Jadi, penguasaan aspek bilangan juga tergantung kepada pengalaman pada seseorang yang lebih muda mempunyai pengalaman relatif kurang, sebaliknya pengalaman yang tua relatif cukup, sehingga untuk melakukan suatu pemecahan masalah penguasaan aspek bilangan kecakapannya juga kurang.

Berdasarkan pengertian-pengertian diatas, umur dapat kita generalisasikan sebagai sifat pembawaan yang mempunyai pengaruh yang sangat penting dalam perkembangan umur seseorang. Jiwa seseorang mewujudkan adanya perbedaanperbedaan dengan perkembangan jiwa pada masa muda dan dewasa. Umur pendidik pada tingkat kemajuan seseorang dibandingkan dengan kemajuan seseorang yang sudah duduk di tingkat atau jenjang tertentu. Umur atau usia adalah perhitungan umur seorang guru sejak ia lahir hingga waktu umur itu dihitung.

\section{Jenis kelamin}

Menurut (Fakih, 2006) pengertian jenis kelamin merupakan pensifatan atau pembagian dua jenis kelamin manusia yang ditentukan secara biologis yang melekat pada jenis kelamin tertentu. Laki-laki adalah manusia yang memiliki penis, jakala (kala menjing) dan memproduksi sperma. Sedangkan perempuan memiliki alat reproduksi seperti rahim, vagina dan memproduksi sel-sel telur. Alat-alat tersebut secara biologis melekat pada manusia jenis laki-laki dan perempuan dan tidak bisa dipertukarkan karena itu merupakan kodrat atau ketentuan Tuhan.

Terdapat anggapan umum dalam masyarakat yang menyebutkan bahwa perempuan itu lemah karena emosinya lebih besar dibandingkan dengan rasionya. Secara psikologis dan akademis pendapat ini sama sekali tidak terbukti.

Menurut Wiwi (2008) bahwa secara psikologis tidak ada satupun teori yang menyebutkan bahwa laki-laki lebih cerdas dibandingkan dengan perempuan. Hasil tes inteligensi perempuan mendapat skor yang relatif sama dengan laki-laki. Hanya saja, memang tidak dapat dipungkiri adanya perbedaan kecenderungan antara perempuan dengan laki-laki.

Perbedaan ini nampaknya berkaitan dengan struktur otak, khususnya teori otak kanan dan kiri, dan bersifat bawaan. Inilah sebabnya kenapa perempuan relatif lemah dalam pelajaran exact seperti matematika, fisika, kimia dan lainlainnya. Minat perempuan dalam bidang ini sangat sedikit. Meskipun penelitian dari tim Queensland University (1994) menunjukkan bahwa melalui latihan dan program khusus perempuan dapat mencapai prestasi matematika yang relatif sama dengan laki-laki, dikutip dari (Riduan, 2007).

Berdasarkan uraian-uraian di atas, maka dapat disimpulkan bahwa perbedaan kemampuan yang terjadi antara laki-laki dan perempuan nampaknya berkaitan dengan struktur otak, khususnya teori otak kanan dan kiri, dan bersifat bawaan. Laki-laki lebih tertarik pada pelajaran yang bersifat rasional-penalaran sedangkan perempuan lebih tertarik dan mampu mengingat dengan baik pelajaran yang berhubungan dengan hafalan dan tokoh. Namun melalui latihan dan program khusus, perempuan dapat mencapai prestasi matematika yang relatif sama dengan laki-laki. Dari teori-teori diatas, maka yang dimaksud dalam penelitian ini adalah terdapat perbedaan penguasaan aspek bilangan antara guru laki-laki dan guru perempuan. 


\section{Penguasaan Aspek Bilangan}

Menurut Kamus Besar Bahasa Indonesia (1994:533) disebutkan bahwa penguasaan berasal dari kata dasar kuasa yang berarti kemampuan atau kesanggupan (untuk berbuat sesuatu) sedangkan penguasaan mengandung arti proses, cara, perbuatan menguasai atau mengusahakan.

Jadi penguasaan aspek bilangan yang dimaksud dalam penelitian ini adalah suatu perbuatan menguasai: penjumlahan, pengurangan, perkalian, pembagian, operasi hitung campuran, perhitungan yang berkaitan dengan uang, pecahan sederhana, FPB, KPK, perbandingan dan skala, akar dan pangkat.

\section{METODOLOGI PENELITIAN}

\section{Jenis dan lokasi penelitian}

Jenis penelitian digolongkan ke dalam penelitian survey yang bersifat deskriptif-korelatif . Penelitian ini berlokasi di Kecamatan Pangkajene Kabupaten Pangkep

\section{Variabel dan disain penelitian}

Ada dua variabel dalam penelitian ini, yaitu variabel bebas dan variabel terikat. Variabel bebas (independen) yaitu tingkat pendidikan $\left(\mathrm{X}_{1}\right)$, umur $\left(\mathrm{X}_{2}\right)$, jenis kelamin $\left(\mathrm{X}_{3}\right)$ Sedangkan variabel terikat (dependen) adalah penguasaan aspek bilangan (Y). Disain penelitian dapat digambarkan sebagai berikut:

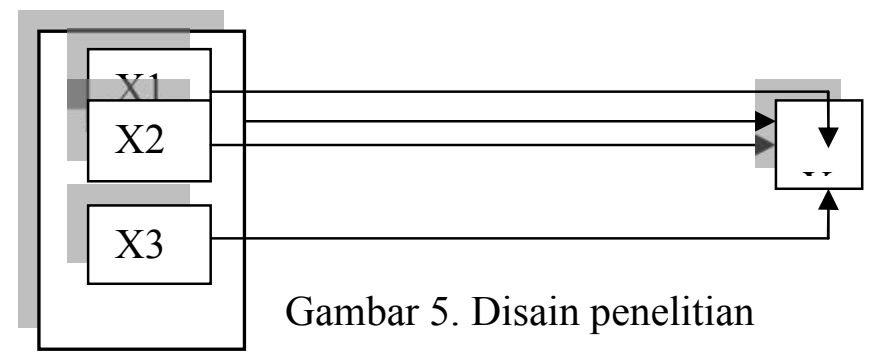

\section{Definisi Operasional Variabel}

Untuk lebih memfokuskan pelaksanaan penelitian, pengumpulan data dan pembahasannya, maka berikut dikemukakan definisi operasional masing-masing variabel, yaitu: (1) Guru SD Negeri adalah guru PNS yang oleh pemerintah dipekerjakan sebagai tenaga fungsional yang mengajar dijenjang pendidikan dasar dan sebagai guru kelas IV, V dan guru kelas VI dilingkungan pendidikan nasional Kecamatan Pangkajene. (2) Tingkat Pendidikan dengan beberapa jenjang pendidikan (SPG/SLTA, D1, D2, D3, S1) adalah lamanya jenjang pendidikan formal yang diikuti oleh guru dalam jumlah tahun. Parameter yang digunakan adalah lamanya tahun menempuh pendidikan formal. (3) Umur atau usia adalah perhitungan umur guru sejak ia lahir hingga waktu perhitungan dilakukan. (4) Jenis Kelamin dalam hal ini bukan perbedaan secara biologisnya, tetapi ditinjau dari perbedaan dalam hal penguasaan terhadap aspek bilangan antara guru lakilaki dan guru perempuan. Untuk keperluan analisis digunakan variabel dummy (variabel boneka) dengan perempuan sebagai level dasar yakni 0 untuk perempuan dan 1 untuk laki-laki. (5) Aspek bilangan adalah operasi hitung sebagaimana yang tercantum dalam BSNP (Badan Standar Nasional Pendidikan) yang meliputi penjumlahan, pengurangan, perkalian, pembagian, operasi hitung 
campuran, perhitungan yang berkaitan dengan uang, pecahan sederhana, FPB, KPK, perbandingan dan skala, penggunaan akar dan pangkat.

\section{Instrumen penelitian}

Untuk mengetahui tingkat penguasaan guru-guru pada aspek bilangan dalam penelitian ini dipergunakan tes. Tes ini merupakan tes penguasaan yang dibuat oleh peneliti dengan mengambil soal-soal UASBN mulai tahun pelajaran 2004/2005 hingga tahun pelajaran 2007/2008 dan soal olimpiade matematika $\mathrm{SD} / \mathrm{MI}$ dengan memperhatikan ruang lingkup materi pelajaran matematika kelas IV, V, dan VI yang berhubungan dengan aspek bilangan. Karena tes yang diberikan diambil dari soal-soal UASBN dan soal olimpiade matematika SD/MI, maka soal tersebut tidak perlu diujicobakan karena telah dianggap valid berdasarkan hasil pemeriksaan beberapa guru matematika yang dianggap layak untuk memberikan keterangan validitas isi. Hal ini didasarkan atas pendapat Arif Furchan dalam bukunya yang berjudul Pengantar Penelitian dalam Pendidikan bahwa: "Untuk memperoleh evaluasi eksternal dari validitas isi, penyusun tes hendaknya meminta sejumlah ahli atau guru-guru lain untuk memeriksa isi tes tersebut secara sistematis serta mengevaluasi relevansinya dengan universum yang sudah ditentukan. Kalau semua penilai itu sepakat bahwa butir tes tersebut dapat dikatakan telah memiliki validitas isi” (Furchan, 2007: 296).

Jumlah butir soal tes penguasaan aspek bilangan yang diberikan adalah sebanyak 30 butir soal. Adapun format tes disajikan dalam bentuk pilihan ganda yang terdiri atas empat alternatif jawaban.. Skor yang diberikan adalah bila jawaban yang dipilih benar, maka diberi skor 1 dan jika salah, maka diberi skor 0 .

\section{Populasi dan sampel penelitian}

Populasi penelitian adalah seluruh guru PNS yang bukan guru pendidikan agama dan guru olahraga pada SDN di Kecamatan Pangkajene yang berjumlah 223 orang dari 30 SDN di Kecamatan Pangkajene. Sedangkan sampel penelitian adalah guru yang mengajar di kelas IV, V dan VI yang berjumlah 65 orang.

\section{Teknik dan prosedur pengumpulan data}

Data diperoleh dari angket dan tes pengetahuan tentang aspek bilangan. Angket dan tes pengetahuan tentang bilangan dibagikan kepada responden untuk dijawab.

\section{Teknik Analisis Data}

Analisis statistik yang digunakan untuk menganalisis data yakni analisis deskriptif dan inferensial. Sebelum analisis deskriptif terlebih dahulu setiap variabel dikategorikan demikian pula sebelum analisis inferensial terlebih dahulu harus memenuhi uji prasyarat(uji normalitas dan uji homogenitas)

\section{HASIL PENELITIAN DAN PEMBAHASAN}

1) Tingkat pendidikan

Pendidikan terendah guru SDN di Kecamatan Pangkajene adalah SPG/SLTA (6,15\%), Diploma (35,39\%) dan pendidikan tertinggi adalah Strata satu $(58,46 \%)$. Tingkat pendidikan SPG/SLTA dan Diploma berada pada kategori rendah sedang pada tingkat pendidikan S1 berada pada kategori sedang. 
2) Umur

Umur responden pada saat pengambilan data yang termudah adalah usia 24 tahun dan yang tertua 58 tahun. Penguasaan aspek bilangan menurun seiring dengan pertambahan umur responden.

3)Jenis Kelamin

Guru yang menjadi responden terdiri dari 16 orang $(24,62 \%)$ guru lakilaki dan 49 orang $(75,38 \%)$ guu perempuan. Perbandingan guru laki-laki dan guru perempuan 16:49 dengan kata lain guru perempuan mendominasi pada tingkat SD. Hal ini disebabkan pada tahun 70-an minat laki-laki untuk masuk SPG sangat minim dibandingkan perempuan. Penguasaan guru laki-laki pada aspek bilangan berada pada kategori rendah dan penguasaan guru perempuan pada aspek bilangan berada pada kategori sedang.

4) Pengaruh tingkat pendidikan, umur dan jenis kelamin terhadap penguasaan aspek bilangan pada guru SDN di Kecamatan Pangkajene Kabupaten Pangkep.

Tingkat pendidikan berpengaruh positif terhadap penguasaan aspek bilangan, umur signifikan terhadap penguasaan aspek bilangan, namun demikian penguasaan aspek bilangan pada responden menurun seiring bertambahnya umur. Jenis kelamin tidak signifikan terhadap penguasan aspek bilangan. Artinya tidak terdapat perbedaan penguasaan aspek bilangan antara guru laki-laki dan guru perempuan.

Besarnya sumbangan atau konstribusi variabel tingkat pendidikan, umur, dan jenis kelamin terhadap penguasaan aspek bilangan pada guru SD Negeri di Kecamatan Pangkajene Kabupaten Pangkep dapat dilihat dari perolehan koefisien determinasi yaitu $\mathrm{R}^{2}=0,284$. Nilai ini memberi pengertian bahwa 28,4 persen variasi penguasaan aspek bilangan pada guru ditentukan atau dijelaskan oleh tingkat pendidikan, umur, dan jenis kelamin dengan demikian 71,6 persen dijelaskan oleh faktor lain.

5) Faktor lain yang ikut berpengaruh terhadap penguasaan aspek bilangan

Dari hasil eksplorasi yang dilakukan terhadap 6 responden dengan menggunakan metode barisan (sequential methode) diperoleh suatu kesimpulan bahwa penguasaan aspek bilangan erat kaitannya dengan: (1) Pendidikan dan pelatihan khusus bidang studi matematika belum pernah diselenggarakan di Kabupaten Pangkep (2) Pendidikan dan pelatihan yang diselenggarakan oleh Kelompok Kerja Guru (KKG) hanya berkisar pembuatan perangkat pembelajaran tidak menyentuh pada pendalaman materi. (3) Rekruitmen guru pemandu berdasarkan penunjukan langsung bukan melalui tes kemampuan. (4) Peran serta guru pemandu matematika belum memadai. Hal ini disebabkan tidak ada jadual khusus untuk bidang studi matematika melainkan masih menyatu dengan KKG. (5) Materi-materi yang disajikan guru pemandu dalam KKG berkisar tentang pembuatan perangkat pembelajaran matematika (KTSP). (6) Beban mengajar guru kelas sungguh luar biasa karena harus menyiapkan berbagai perangkat pembelajaran bidang studi lainnya sehingga tidak ada waktu untuk lebih memperdalam materi. (7) Kurangnya perhatian dari pihak yang terkait, baik dari segi motivasi maupun dari segi insentif. (8) Tidak dilakukannya pergeseran jenjang kelas sehingga guru kelas IV, V dan VI hanya mempelajari materi ajar masing-masing dengan alasan bila terjadi pergeseran maka harus membuat ulang 
perangkat pembelajaran dari beberapa bidang studi. (9) Minimnya pengetahuan tentang matematika karena pada umumnya berasal dari jurusan Bimbingan Konseling.

\section{SIMPULAN DAN SARAN \\ Simpulan}

Berdasarkan hasil penelitian yang telah dikemukakan, maka dapat ditarik kesimpulan sebagai berikut: (1) Penguasaan aspek bilangan pada guru SD Negeri di Kecamatan Pangkajene Kabupaten Pangkep, berada pada kategori rendah. Ini berarti kompetensi yang harus dimiliki oleh guru SD pada aspek bilangan belum tercapai, bahkan perlu pendidikan dan pelatihan khusus bidang studi matematika untuk meningkatkan kualitas pendidikan di Kabupaten Pangkep. (2) Tingkat pendidikan, umur, dan jenis kelamin secara bersama-sama berpengaruh terhadap penguasaan aspek bilangan pada guru SD Negeri di Kecamatan Pangkajene Kabupaten Pangkep (3) Tingkat pendidikan mempunyai pengaruh yang berarti terhadap penguasaan aspek bilangan pada guru SD Negeri di Kecamatan Pangkajene Kabupaten Pangkep. Hal ini menjelaskan bahwa tingkat pendidikan merupakan variabel penting diperhatikan dalam menjelaskan penguasaan aspek bilangan. (4) Penguasaan aspek bilangan menurun seiring dengan bertambahnya umur guru SD Negeri di Kecamatan Pangkajene Kabupaten Pangkep. (5) Penguasaan aspek bilangan pada guru SD Negeri tidak dapat dijelaskan oleh faktor jenis kelamin. Dengan demikian tidak terdapat perbedaan penguasaan aspek bilangan antara guru laki-laki dan guru perempuan pada SD Negeri di Kecamatan Pangkajene Kabupaten Pangkep. (6) Pendidikan dan pelatihan, latar belakang pendidikan, pergeseran jenjang kelas, peran serta guru pemandu, motivasi kerja, serta insentif merupakan faktor yang ikut mempengaruhi penguasaan aspek bilangan pada guru SD Negeri di Kecamatan Pangkajene.

\section{Saran}

Berdasarkan hasil penelitian dan kesimpulan yang telah dikemukakan di atas, berikut ini diajukan saran yang diharapkan dapat menjadi pertimbangan sehubungan dengan upaya peningkatan kualitas pendidikan di Kabupaten Pangkep sebagai berikut: (1) Untuk meningkatkan kualitas pendidikan di Kabupaten Pangkep, maka disarankan kepada guru SD Negeri di Kecamatan Pangkajene untuk studi lanjut demi meningkatkan kompetensinya. (2) Demikian pula kepada para kepala sekolah agar melakukan pergeseran jenjang kelas untuk kelas IV, V, dan VI, serta senantiasa memotivasi gurunya untuk berprestasi. (3) Kepada para pengawas agar senantiasa memonitorin kegiatan KKG yang ada di wilayah masing-masing, sehingga pelaksanaan KKG efektif dan efesien. (4) Kepada pemerintah daerah Kabupaten Pangkep agar segera memprogramkan pendidikan dan pelatihan khusus bidang studi matematika secara berkesinambungan dan dalam hal merekrut guru agar memperhatikan latar belakang pendidikan demi meningkatkan kualitas pendidikan di Kabupaten Pangkep. (5) Kepada peneliti yang lain disarankan agar menelusuri penguasaan aspek bilangan dari segi pemahaman konsep dan mengkaji lebih dalam tentang faktor-faktor lain yang berkaitan dengan penguasaan aspek bilangan. 
DAFTAR PUSTAKA

Ary, Donald. Luchy Cheser Jacobs dan Asghar Razavieh. 1982. Pengantar Penelitian Dalam Pendidikan. Terjemahan oleh Arief Furchan. 2007. Yogyakarta: Pustaka Pelajar.

Badan Standar Nasional Pendidikan. 2006. Standar Isi Kurikulum Tingkat Satuan Pendidikan SD/MI. Jakarta

Ediati, Srihari. Mendidik Anak Menyukai Berhitung dengan Matemagica. Online (http://marthatanti.multiply.com) Diakses pada tanggal 15 Maret 2008.

Fakih, Mansour. 2006. Analisis Gender dan Transformasi Sosial. Yogyakarta: Pustaka Pelajar.

Hamalik, Oemar. 2008. Pendidikan Guru Berdasarkan Pendekatan Kompetensi. Jakarta: Bumi Aksara.

Heruman. 2007. Model Pembelajaran Matematika di Sekolah Dasar. Bandung: Rosdakarya.

Jalaluddin. 2001. Teologi Pendidikan. Jakarta: Raja Grafindo Persada.

Kamus Besar Bahasa Indonesia Edisi Kedua. 1994. Jakarta: Balai Pustaka.

Ma'rufi, 2006. Analisis Partisipasi Masyarakat dan Faktor-faktor yang Mempengaruhi dalam Pengelolaan Lingkungan Kota Palopo. Tesis tidak diterbitkan. Makassar: PPs UNM.

Mulbar, Jalaluddin. 2007. Pokok-Pokok Materi Matematika Dasar. Makalah disampaikan pada pelatihan guru pemandu mata pelajaran matematika SD se kabupaten Luwu Timur.

2007. Matematika Dasar Operasi Hitung Bilangan. Makalah disampaikan pada pelatihan guru matematika SD kota Pare-Pare.

Pidarta, Made. 1997. Landasan Kependidikan Stimulus Ilmu Pendidikan. Surabaya: PPs Pendidikan Matematika IKIP Semarang.

Ratumanan, T.G. 2004. Belajar dan Pembelajaran: Edisi Kedua. Ambon: Unesa.

Riduan. Pendidikan dan Pemberdayaan Perempuan. Online

(http://desangayau.blogspot.com/2007) Diakses pada tanggal 20 April 2008.

Retiyono dkk. 2007. Persiapan Menghadapi Ujian Akhir Nasional/ Ujian Akhir Sekolah Wajar Sekolah Dasar/Madrasah Ibtidaiyah 2007/2008. Surabaya: Pustaka Agung.

Sagala, Syaiful. 2003. Konsep dan Makna Pembelajaran. Bandung: Alfabeta.

Slameto. 2003. Belajar dan Faktor-faktor yang mempengaruhinya. Edisi Revisi. Jakarta: Rineka Cipta.

Sobel, Max A. 2004. Mengajar Matematika Sebuah Buku Sumber Alat Peraga, Aktivitas, dan Strategi: Edisi Ketiga. Jakarta: Erlangga.

Sobirin. 2008. Menjadi Juara Olimpiade Matematika SD/MI. Jakarta: Media Pusindo.

Soedjadi. 2000. Kiat Pendidikan Matematika di Indonesia. Direktorat Jenderal Pendidikan Tinggi Departemen Pendidikan nasional.

Sudjana. 1996. Metoda Statistika. Edisi ke 6. Bandung: Tarsito. 
Sudrajat, Akhmad. Manajemen Strategis Kepemimpinan Pendidikan. Online (http://akhmadsudrajat.wordpress.com) Diakses pada tanggal 25 Mei 2008. Sugiyono. 2008. Metode Penelitian Pendidikan Pendekatan Kuantitatif, Kualitatif, dan R\&D. Bandung: Alfabeta

Suherman dkk. 2003. Strategi Pembelajaran Matematika Kontemporer. Jica. Universitas Surabaya.

Syah, Muhibbin. 2006. Psikologi Pendidikan dengan Pendekatan Baru. Edisi Revisi. Bandung: Rosdakarya.

Tatang Rahmat dkk. 2007. Persiapan Menghadapi Ujian Akhir SD 2008. Edisi 5 Tahun. Bandung: Pustaka Setia.

Tiro, M. Arief. 2000. Analisis Korelasi dan Regresi. Makassar: State University of Makassar Press. . 2002. Statistika Terapan untuk Ilmu Ekonomi dan Ilmu Sosial. Makassar: Andira Publisher. . 2004. Analisis Regresi dengan Data Kategori. Edisi Kedua. Makassar: State University of Makassar Press. Andira Publisher.

Undang-Undang Guru dan Dosen. 2005. Undang-Undang RI No. 14. Jakarta: Sinar Grafika.

Usman, Moh. Uzer. 2007. Menjadi Guru Profesional. Edisi Kedua. Bandung: Rosdakarya.

Winkel, W.S. 1996. Psikologi Pengajaran. Jakarta: Gramedia 